by Dr. Leonard Dobbin, a considerable amount of magnesia, and thus approaches a magnesian limestone.

4. Compact fawn-coloured crystalline limestones of a homogeneous texture, in which sometimes reef débris may be observed. These rocks, which are of common occurrence on the lower slopes of the large island of St. Christoval, where they overlie the volcanic rocks of the district, are apparently formed by the consolidation of the ooze found at the bottom of lagoons inside coral reefs.

5. Foraminiferal limestones, which are hard and compact in texture, and are chiefly made up of pelagic and bottom-living Foraminifera, and contain occasionally a few simple corals of deep-sea genera. They contain generally from 7.5 to 85 per cent. of carbonate of lime, the residue being formed of the common volcanic minerals, siliceous casts of Foraminifera and fine argillaceous matter. These limestones are found at the surface, and in the island of Alu they may be seen to overlie the soft Foraminiferous and Pteropod deposits.

Such are the calcareous formations which are of most frequent occurrence in the Solomon Islands. Three other highly interesting rocks came under my notice, but in each case only in one locality.

(a) A Rhynconella limestone. In one of the islets of the Shortland Islands I found a hard grey limestone composed of numbers of Brachiopod, Gasteropod, and Lamellibranchiate shells, with many simple corals of deep-sea genera, embedded in a calcareous matrix largely made up of the tests of Foraminifera (chiefly pelagic forms). The Brachiopod shells belonged to the same species of Rhynconella. Mr. Davidson is inclined to look upon it as the same as $R$. Grayii, a species hitherto represented by a single specimen discovered in the British Museum amongst other natural history objects from the Fiji Islands (?) collected by Mr. J. M'Gillivray more than thirty years since. ${ }^{1}$ The simple corals, as Mr. Quelch informs me, belong to the deep-sea genera, Leptocyathus, Stephanophyllia, Odontocyathus, Flabellum, \&c. The Gasteropod and Lamellibranchiate shells are, as I learn from Mr. E. Smith, of shallow-water habit. This limestone contained 75 per cent. of carbonate of lime, the residue being made up of the common volcanic minerals, reddish siliceous casts of Foraminifera, and fine washings.

(b) A friable earthy rock, which, from the small size of the minerals, the absence of bottom-living Foraminifera, and the scarcity of pelagic forms, resembles a deep-sea clay, and contains a thin coating of manganese between the small layers or folds of the rock. This deposit, which contains about 20 per cent. of carbonate of lime, occurs in the upraised atoll of Santa Anna underneath the elevated reef-mass. On the reef-flat in the vicinity of this deposit there was observed by Lieut. Malan, as already observed, a detached concretionary block of manganese peroxides, one to two cubic feet in size : a typical fragment that I brought home is, according to Mr. Murray, quite similar to smaller masses dredged by the Challenger and Blake.

(c) A hard Foraminiferal limestone, chiefly composed of pelagic Foraminifera. Of this rock, which was found at the surface in Treasury Island, Mr. Murray observes that the organisms, together with the minerals, are similar to those found in deposits of modern seas near volcanic islands at depths of from 500 to 800 fathoms. The Foraminifera are identical with those found in the surfacewaters of the tropics at the present day.

With such data as the foregoing at my disposal, it might appear an easy matter to gauge the amount of elevation that has occurred in these regions in recent times. But so great has been the sub-aërial denudation in these islands that although the elevatory movements have brought up to our view a deep-sea clay, with its concretion of manganese, and a Foraminiferal limestone that was probably formed in a depth of from 500 to 800 fathoms, two rocks

${ }^{1}$ Vide Annals and Magazine of Natural History, vol. xvi. p. 444. which occur in islands at opposite extremities of the group, yet, notwithstanding this great upheaval, the calcareous envelopes usually disappear from the slopes of the volcanic islands at heights of 500 or 600 feet above the sea, and never came under my observation in such islands at greater elevations than 900 feet. The rainfall in the elevated interior of the large islands cannot be much under 300 inches in the year, since my own observations place it at about 150 inches at the coast. Of the rapid degradation of the surface which these calcareous districts undergo during a heavy fall of rain, of as much as two to three inches in the same number of hours, I was a frequent witness. In a few minutes the whole hill-slope discharges a continuous sheet of muddy water, the rivulets swell to turbid streams, and the water rushes down the permanent courses with the roar of a mountain torrent. After the rain-storm has passed away, the band of muddy water that fringes the whole length of the coast, to a distance of one-quarter or one-third of a mile from the shore, indicates the loss of material which the land-surface has sustained.

From the general character of these calcareous formations it may be safely inferred that they will be found wherever there has been elevation during the recent period in regions where coral reefs are flourishing. Amongst other localities we may look to the West Indies, the Indian Archipelago, New Guinea (more particularly the southcoast), New Britain, New Ireland, the Santa Cruz Group, the New Hebrides, the Loyalty Islands, New Caledonia, and the Fiji and Tonga Groups, as likely to possess at the sea-border formations of a similar character. In the Solomon Islands, many other islands, such as Ulaua and Ronongo, will be probably found to be counterparts of the islands of Ugi and Treasury.

NOTE.-A reference should be made to the occurrence of worked flints of the palæolithic type in the soil of the cultivated districts of these islands. The natives say they have fallen from the sky, which reminds one of a similar superstition prevalent in the country districts at home as to the source of celts. I was never successful in finding where they came from originally, and would recommend future visitors to this group to pay attention to this point. They are said to occur together with a chalk-like rock on the beaches of Ulaua, an island which I was unable to visit. (For further information on this subject, vide some notes of my own read by Prof. Liversidge before the Royal Society of New South Wales, Foumal for 1883 , vol. xvii. p. 328.)

\section{TRACING A TYPHOON TO EUROPE}

$A \mathrm{~T}$ the meeting of the Royal Meteorological Society held on November 18, a paper by Mr. Henry Harries, on "The Typhoon Origin of the Weather over the British Isles during the second half of October, I 882," was read. The author had prepared daily charts of the North Pacific Ocean from September 26 to October 10, and by permission of the Meteorological Council the charts of the area between the western coast of America and Eastern Europe were utilised. The earliest evidence of the formation of the typhoon was on September 27, some distance east-south-east of Manilla. At first the movement was towards north-west, 5 miles an hour, but on September 30, when the storm-area extended to 1300 miles north-west of the centre, it curved towards north-east, crossed the south-eastern corner of Japan at 33 miles an hour, and attained a maximum rate of 5 I miles per hour on October 2 to 3, after leaving the Japanese coast. In the neighbourhood of the Aleutian Archipelago the progress was very slow until the gth, when it rapidly increased to 35 miles an hour, and entered Oregon on the Ioth. The Rocky Mountains proved to be no obstacle to the progress of the typhoon, which crossed the range at $36 \frac{3}{4}$ miles an hour, and, maintaining this rate, passed 
across the Northern States into Canada. Thence it crossed Hudson's Bay and Labrador, into Davis Strait. Altering its course to south of east it passed the southern point of Greenland on October 16, and two days later, in lat. $55^{\circ}$ N., long. $27^{\circ}$ W., it was joined by another disturbance, which seems to have formed about October 9 in $20^{\circ} \mathrm{N} ., 48^{\circ} \mathrm{W}$. The junction of the two storms was followed by a complete cessation of progressive movement for a week (October 19 to 25), and it was during this period was formed as a subsidiary the gale which suddenly arrived over our south-eastern counties upon the morning of October 24, completely upsetting the Meteorological Office forecasts of the previous night The author quoted several records from ships, which went to show that this secondary storm had not formed until nearly midnight; and that reports from outlying coast-stations would not have enabled successful forecasts to be issued before $3 \mathrm{a} . \mathrm{m}$. on the 24th. The $8 \mathrm{a} . \mathrm{m}$. observations for the Daily Weather Report show that with the exception of Hurst Castle the winds on the northern side of the Channel were moderate, but along the French coast heavy gales were blowing. Ships' records indicate that off Start Point a moderate easterly gale began at 6.20 a.m. By $S^{\prime}$ a.m. a whole gale from S.E. was blowing

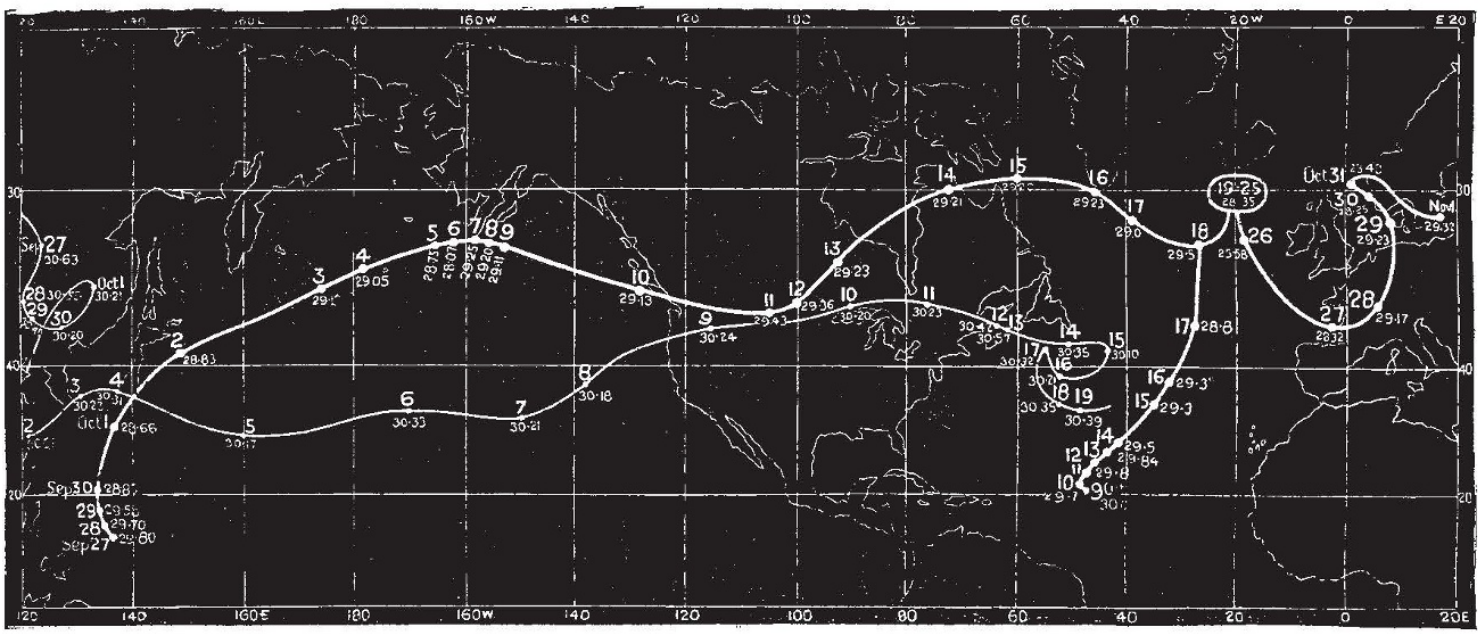

Tracks of the Typhoon and Anticyclone of September and October 1882 . The thick line shows the track of the typhoon, the thin line that of the anticyclone. The dates and the lowest and highest ascertained readings of the barometer for the day being given near the positions of the centres at Greenwich noon.

to south-west of Portland, while off the Start at 8.30 a.m. the wind veered to W.N.W. a strong gale. At 9 a.m. the wind off Portland veered to W. and blew with terrific violence. Further east, as far as the Downs, the wind had by noon changed to W. and S.W., and increased to a furious storm, with violent squalls and a terrible sea. As this gale passed away the primary moved into the Bay of Biscay and entered France on the 27th. As in Japan and America, its advance was marked by violent gales and destructive floods over a very extensive area-from Algeria northwards. The damage caused by the floods in

\section{THE NIVAL FLORA OF SWITZERLAND}

I $N$ the spring of 1883 (the last year of his life), the eminent Swiss naturalist, Prof. Oswald Heer, having finished his "Flora fossilis Arctica," resumed a work with which he had been long occupied before-viz. the preparation of a Nival Flora of Switzerland, in which he proposed to give an account of all the plants found above 8000 feet in that country, and a comparison of these with the Nival flora of other countries. This work, based on very abundant material, was nearly completed before the author's lamented death; - - he anticipated being able to finish it in about eight days more had health allowed. The work has now been published in full (as he left it) in the Nouveaux Mémoires de la Société Helvétique des Sciences Naturelles (vol. xxix. part I). The summary of results of this research, which were communicated at a gathering of Swiss naturalists in Zurich, we will here reproduce.

(I) We know at present in Switzerland 337 species of flowering plants which have been observed at from 8000 to 13,000 feet above the sea; 12 of these species have still been found above 12,000 feet.
England was serious, but trifling compared with the losses in Southern and Central Europe, the destruction being enormous. This typhoon was the principal contributor in making October, I 882, by far the worst within living memory. With this final effort it seemed to have expended its fury, and in crossing France and the Netherlands it gradually filled up. The last trace of the typhoon was in the Baltic on November I, when it quietly dispersed, after covering over I4,000 nautical miles in thirty-six days, the longest track hitherto followed day by day.
(2) All these species are found in the lowest division of the Nival region, 8000 to 8500 feet. Above 8500 feet there is no species which is peculiar to this height.

(3) One-tenth of the species of the Nival region consists of species of lowland flora, nine-tenths of mountain plants. Most of the latter belong to the Alpine region, and about a quarter of the species has its greatest distribution over 8000 feet. These are the Nival plants in the narrower sense. While the lowland plants and the plants of the hilly and sub-Alpine region disappear at about 9500 feet, the Nival plants, with a few Alpine species, are the last children of the flora.

(4) The mountain mass of Monte Rosa has the richest Nival flora ; which here rises higher than in the Rhæetian Alps, and in the latter higher than in the Glärnisch Alps.

(5) The majority of the species are distributed throughout the whole region of the Alps; only a small portion is found exclusively in the east from Orteler to the Gothard, or in the west from the Gothard to Savoy.

(6) About half of the plants of the Nival region come from the Arctic zone, and very probably came over Scandinavia to our region in the Glacial period, since Arctic Europe has the largest number (140) of species 